\title{
EFL Students' Attitude Toward Learning English
}

\author{
Meul Isti', Lutfi Istikharoh ${ }^{2}$ \\ Universitas Muhammadiyah Purwokerto \\ Email : meulisti@gmail.com
}

Keyword :

EFL Learning,

Attitude,

Attitudinal Factors

DOI :

10.30595/jssh.v3i2.3126

\begin{abstract}
The purpose of this research was to analyze EFL students' attitude toward learning English based on three aspects namely affective, cognitive and behaviour and to find out factors shaping students' attittude. This research was conducted in a public junior high school in district Sokaraja. This research belongs to survey study in which the researcher took $30 \%$ from population as the samples. The researcher chose 7 th grade students to get involved as the participants. In order to answer the research questions, three instruments were used. Those were questionnaire, interview guide, and note taking of observation. Based on the result of the study, students had possitive attitude in those overall aspects. However, the behavioural aspect comes first accounting for $68,8 \%$ followed by affective aspect accounting for $68,10 \%$. Those were higher compare to cognitive aspect which was accounted for just $64,7 \%$. Then it was supported by the results of observation and interview in some points of each aspect. In addition, the result of questionnaire and interview displayed six factors affecting students' attitude: mass media, refference group, teacher, personal experience, parents and the last is learning climates and classroom task. Some results of factors shapping students' attitude were also supported by the interview.
\end{abstract}

\section{INTRODUCTION}

\subsection{Background}

Indonesian government has put English as a compulsory subject in Indonesian education particularly in junior and senior high school. It is formally introduced into primary schools from year 4 and continues to year 6 . At university level, English is a requirement for all faculties and undergraduate majors (Yulia, 2013, as cited in Sulistiyo, 2016).

Further, eventough English has been introduced since elementary schools, nevertheless, it seems hard to achieve the goals of English learning, especially for
Indonesian students in which they are lack of exposure. Further, English in Indonesia is more likely to be taught and learnt only as a foreign language. It means that they do not use the language outside the calss.

Although English is taught and used as a foreign language in Indonesia, and there have been many years of English instruction in formal schooling, the outcomes are unsatisfactor as stated by Lie (2007)cited in Sulistiyo (2016), There are some factors that might affect the learning outcomes. It can be from the students or the environment like teacher, learning, achievement, etc., as stated (Shams, 2008, as 
cited by Jafre, Mohamad Zainol Abidin, 2012). Within several factors, it is argued that attitude is the most important factors that contributes to learning success as stated by Fakeye, "The matter of learners attitude is acknowledged as one of the most important factors that impacts on learning language (Fakeye, 2010 as cited by Jafre, Mohamad Zainol Abidin, 2012).

Thus, due to the importance of revealing Students' attitude in learning English, an investigation of it becomes a fruitful thing to conduct. Therefore, a research entitled EFL Students' Attitude Towards Learning English is needed to do.

\subsection{Literature Review}

\subsubsection{English as a Foreign Language}

In Indonesia, English is considered as predominantly a foreign language. It means, that language is commonly taught in schools alongside other subjects, such as mathematics, biology and physics (Sulistiyo, 2009, as cited by Sulistiyo, 2016).

In addition, Gebhard (2006) as stated by Santoso Agus, 2006, EFL can be defined as the study of English by people who live in places in which English is not used as a means of first language communication.

To sum up, English as a foreign language means that English is not used for daily conversation. This situation made the students feel hard to practice English they got from school in everyday live.

\subsubsection{Attitude of Learning}

As attitude is one of the important key factors for succsess in language learning. Within some definitions of attitude, Wenden (1991) as cited by Salim Saleh Khalaf Ibnian (2017), presents a comprehensive definition of the attitude concept. He classified the term "attitude" into three interrelated components namely, cognitive, affective and behavioral. The cognitive component involves the beliefs, thoughts or viewpoints about the object of the attitude. The affective component refers to the individual's feelings and emotions towards an object, whether he/she likes or dislikes. The behavioral component involves the tendency to adopt particular learning behaviors.

\subsubsection{Affective component}

It is also called emotional aspect of attitude. The characteristics of affective component covers some indicators including students' acceptance towards the learning, students' responses in learning English, appreciation towards English learning, organizing a good habit or consistency and practicing English (Hasyim Zaini, Desain Pembelajaran Perguruan Tinggi, 2002, pg.74-76 as cited Syeh Hawib Hamzah, 2012).

Most of the indicators above can not be observed directly since people can not see what other people feel, people can not see the level of students readiness that lead them become active, their loyality towards the use of knowledge, their consistency towards learning English in class or outside class room and how they practice their knowledge.

\subsubsection{Cognitive component}

It includes the beliefs of the language learners about the knowledge that they acquire and their understanding in the process of language learning. The cognitive aspect involves many of mental activities or brain. The capabilities and domains of cognitive are categorized by Bloom into six levels. Harjanto, Perencenaan Pengajaran, (Jakarta: Rineka Citra, 2003), hal. 59 as cited in Syeh Hawib Hamzah, 2012.

First, Memorizing. It refers to the students' ability to memorize and restate the previouse material, the second, understanding towards the concept, third, students' ability to analyse certain tasks, fourth, students' ability to compose or produce words or tasks and the last is evaluation, share values or ideas to others.

To reveal those components in a learning, researcher has to come directly to 
classroom and see the learning process from the beginning until the end.

\subsubsection{Behavioural component}

The behavioural aspect of attitude is related with the way one acts or behaves in particular situations. This component is divided into seven levels. Ibid, hal. 62-76 as cited in Syeh Hawib Hamzah, 2012.

Those are students' perception or the use of sense organs to do activity, students' readiness or activeness, students' ability to do imitation or guided responses, students' confidence to do certain movements started from accostumed movement, complex movement, adjustment of the pattern of movement and, and creativity.

In behavioural aspect, most activities are done through certain movements. Since behaviour or movement have to be observed directly, thus the main methode to gain data about this is by doing observation in classroom

\subsubsection{Factors Affecting Attitude of Learning}

There are some factors affecting the way students perform in the classroom.

First, parents. It is believed that parents have a major role in second/foreign language process. There are two roles of parents as stated by Gardner (1977) as cited by Yazigy, Rula Jamil (2015), those are active or passive.

Second, Teachers. Teacher are suggested to have personal and professional characteristics which can affect students attitude of learning English. Similiarly Gardner (1977) as cited by Yazigy, Rula Jamil (2015), also stated that teacher play a significant role in the foreign language learning process.

Third, Learning climate and classroom task. The climate is manifested in terms of factors such as quantity and quality of the resources available, phisical environment of the class and acceptance by the teachers in the class (Mariadass \& Kashef, 2012) as cited by Ganaphaty, Malini (2016).

Fourth, reference group. Peers or certain groups that have good influence in learning English tend to have important role in shaping attitude.

Fifth, Personal Experience. Lepy, (Attitude an Social Cognition pg. 111) stated that many attitudes are formed not in the family environment or through reference groups, but through direct personal experiences which bring about a drastic change in someone's attitude.

The last, mass media. The media can exert both good and bad influences on attitudes.

\section{METHOD}

This research was conducted at SMP N 2 Sokaraja in academic year 2017/2018. The population used in this research was all students of 7 th grade level in SMP N 2 Sokaraja. the researcher took $30 \%$ from the population as the sample. Therefore, the total of the samples were 93. Within many sampling techniques, random sampling was chosen to take the sample.

\subsection{Research Instruments}

In this study, there were three types of data collecting method used namely questionnaire, interview and observation. Questionnaire was uded to get data about students' attitude and factors contributing students' attitude, meanwhile observation and interview were used to support the result of questionnaire as well as to find out data which could not be obtained thorugh the main instrument.

\subsection{Data Analysis}

Data that had been gathered should be analysed or processed to be meaningful. By analysing data, a researcher is able to get conclusion. Since there were three methods of collecting data hence the researcher used triangulation to analyse the data. 


\section{RESULTS AND DISCUSSION}

Based on the questionnaire, it can be seen that most of students have good attitude towards learning English in three aspects. The result can be seen more easily in chart belows.

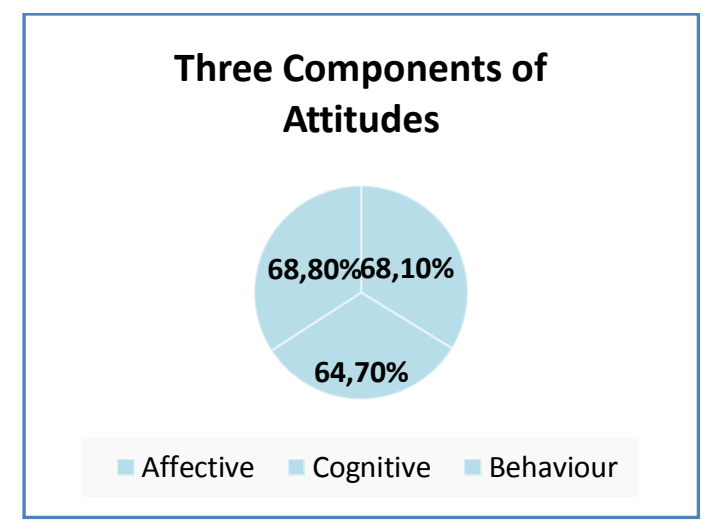

Fig 3.1. The Precentage of Three Attitudes' Components

The highest percentage was in the behaviour component in which there were $68,8 \%$ students stated that they gave full attention towards learning English. They neither talked with their friends while learning nor playing their cellphone. The second position reveals that students have good attitudes in affective aspect which was calculated $68,10 \%$. Then cognitive aspect was $64,70 \%$.

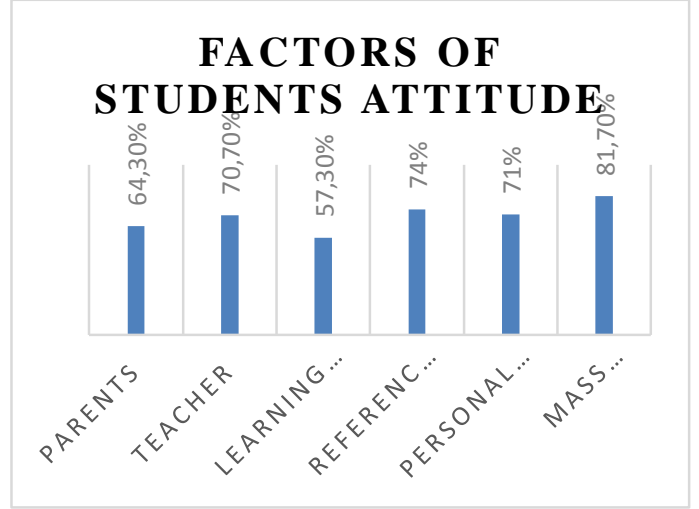

Fig 3.2. The Precentage of Factors Contributing Students' Attitude

Six items of factors contributing students' attitude show that the most influencing factor which affect students' attitude towards learning English was mass media. It is $81,7 \%$ students stated that Mass Media really helps them learning English. It eases them to do several tasks. Then the factor of refference group was $74 \%$ and then personal experience was $71 \%$, teacher was $70,7 \%$, parents influence was $64,3 \%$ and the last is learning climates and classroom tasks which was only $57,3 \%$. In conclusion the most influencing factors contributing to their attitude refers to mass media.

3.1. Attitudes of EFL Students Towards Learning English Language In Terms of Their Affective, Behavioral And Cognitive Aspects

According to the questionnaire result, overall aspects achieved the criterion of good attitudes. The percentage of affective aspect is $68,10 \%$, this is the second position after behavioural aspect which was calculated $68,80 \%$. In addition those percentages were higher in compare to cognitive aspect accounting for just $64,70 \%$. This result obviously shows that students had possitive attitude Some evidences prove the result of questionnaire especially in affective component. First, during the observation in some classes it was found that most students came on time in the class. Even, many of them had prepared the course book on the table. Thus, hey tend to be decipline. This is in line with the result of questionnaire which was counted $40 \%$ of students agreed that they always come on time in to the class.

This might be the consequences of having good interest to learn English as found that the presentage for students' interest towards learning English was $69,9 \%$. Then, students respons were also possitive especially when the researcher asked about like and dislike of studying English. Most students that had been interviewed stated that they like learning English because learning English is fun and they also want to continue to study to abroad.

To get the reason, the researcher asked other question related to the importance of learning English. Supprizing, more than 
half of the samples stated that learning English is important. The second evidence got from observation which proves that many students seemed cheerfull especially when they were working in group. This finding supports the item of questionnaire accounting for $73,9 \%$ of students feel happy when learning English.

There is a notable decrease between students' acceptance and their responses. From the questionnaire it was calculated that $60,9 \%$ of students were willing to give contribution in order to get succsess in learning English. The types of contribution stated in the questionnaire was the willingness to join English course to develop their English skill. In addition, other contribution that can be explored by the researcher through observation differs. There were only small number of students contribute themselves in learning English. Based on what was seen by the researcher, only 4-6 students were active to respon teacher's question or come forward.

The finding obtained from interview reveals that some students they felt nerveous and unconfident to state ideas or giving opinion. They were also afraid of being wrong. Meanwhile, Other students stated that if they knew the answer they will be confident.

Even tough the EFL students had a problem especially their activeness when learning English in the classroom, but their appreciation towards English was quite good. It is shown that accounting for $56,8 \%$ students were willing to practice English in everyday live. However, the result of interview shows the opposite. Many of them did not practice English outside the class. It is because English is not used to speak in daily live. They use Indonesian language or first language instead.

Even tough their effort to master English is still low, but when the researcher asked them about the importance of learning English, they realized that learning that language is important. The researcher also got some arguments about why it is important to learn English. First, it is important to continue study to abroad, then it is important to do national examination and communicate with foreign people. Camenson also says that EFL students which their own language is primarily spoken may required to learn English for thier academic studies, travelling activities to an English speaking country, or for business purposes (Camenson, 2007 cited by Susanto, Agus, 2010).

Dealing with students' responses and appreciation towards English, there will be organization. Organization refers to combining values or believes that they trust then build a system that is consistent. Based on the result of questionnaire students' consistency in learning English was good accounting for $62,2 \%$. Some students stated that sometimes they read again the material at home.

The next indicator that can also support this finding is practicing. From the questionnaire distributed, the presentage of students' willingness to practice English skill in daily live is $70,7 \%$. It is categorized good which means that many students were willing to use English in daily live, in this case is to watch movies in English subtittle and listening to English song.

To sum up, students affective aspect was good especially how they accepted the learning and how they were willing to practice it eventough they have no large spaces to explore English outside.

Moreover, students that have good affective aspect can be possible to have possitive or negative aspect of cognitive, the second aspect of attitude. This survey found that students had good cognitive aspect accounting for $64,7 \%$, the lowest than the others. 
Having analyzed the questionnaire, the researcher reveals that students' ability to memorize previouse material was good. However, the observation shows the opposite. Only several students spoke when the teacher evaluate the previous material. Their memorization tend to be stronger if they have understood the concept of the materials. Nevertheless, there are still possibilities that make them forget about the material. Such as, the finding above which reveals that sometimes students read the material again but sometimes they did not or their opinion is neutral about this case. So, consequently they will be easier to forget the previouse material. Other finding which supports this is because they were rarely to practice English in daily live. Similiarly, Camenson posits that EFL students only spend a view hours per week to study English. They have no much exposure to English outside the classroom and have little opportunity to practice their newly-acquired language skills (Camenson, 2007 cited in Susanto, Agus, 2010).

Talking about understanding, the cognitive aspect can also be known through their respons towards the understanding of the material. Based on the questionnaire, students' understanding was good. In addition, after the researcher observed in the classroom, it was found that many students seemed understand about the concept given. As the observation shows that some of them could answer teacher's question and when the teacher offered questions to check their understanding, no commen or respon given from students. Even some of them said they have understood. In line with this, the interview reveals that the material was easy to understand.

After checking students' understanding, the researcher also needed to check whether they could use the concept easily or not. According to the item of questionnaire, the ablity to apply the concept was accounted for $64,5 \%$. The result is recognized good. Then the observation shows that, many students could do the task from the teacher. For example, when they interviewing others about habitual action, then listing vocabs of thing arround home and the function and many others. Some students also stated in an interview that sometimes the task is easy, sometimes is not. If it is not then if they work in group they will find it easier to finish the task.

Dealing with task, ideally the tasks given to students are graded from the easier to the most difficult one. The result of observation shows that students were able to discuss and solve problem especially in group. For example when students were asked to anlyse a video, then did interview by making question, etc,.In that activity, almost every member also participated to give their idea. This result supports the questionnaire in which students ability to analyse problem or task given by the teacher accounting for $66,5 \%$. In line with this, the interview reveals that they could solve problem or task given by the teacher especially when they did it in group.

After analysing problem, usually there will be the next stage of learning namely production. According to the result of questionnaire, students's ability to compose or produce text is $61,1 \%$, then it is supported by the result of observation, some meetings reveals that some students has quite good ability in speaking, especially E class. Unfortunately not all students had a chance to speak. There was a class that required all students to speak, but their focus was in pronounciation and memorization. Similiarly, Sawir states that teaching and learning activities in EFL classroom mostly involve memorising vocabulary, studying grammar and reading English texts (Sawir, 2005, as cited in Sulistiyo, 2016). 
Further, the researcher asked about this case to students. The result is students still has difficulty in writting or speaking. The reasons were they feel nerveous to speak, then do not know how to say something in English, and also the way betweeen how students write and how they read is different.

Still talking about the stage of learning, usually after the teacher gave tasks, there will be evaluation at the end of learning. It is related with how they can share the result of learning. Based on the result of questionnaire students' opinion about their ability to share the result of learning confidently was good. Then the researcher strengthened the finding by observing them till the end of meeting. In that observation, it could be seen that almost all classes asked students to perform. The first class shown that no students perform confidently, the second class several students perform quite good, then the last class shown that many students were passive and unconfident. Most of them also did not evaluate other friends' work/perfomance eventough teacher had already asked their opinion. The result of interview also supports the finding. Many students said that they were afraid, shy and hesitate to give ideas or share the result in front of class.

Then, the third aspect is behavioural aspect. A succsessfull learning can be seen in the way that students behave in particular situation. Thus, many data could only be taken through observation as it deals with students' activeness and performance. The finding shows that the presentage of students' behaviour is $68,8 \%$. This number is categorized good, even tough the presentage did not represent overall result of behavoural aspect as not all indicators of behaviour can be asked. There were only two points covered in the questionnaire namely preception and readiness.

Students' perception relates to the use of sense of organ to capture signal that guide them to do activity. In preception, students were asked about their attention towards learning English. The result shows that $56 \%$ students strongly agreed that they do not play handphone during the learning. In compare to that, $20 \%$ students also agreed with that statement. The researcher also confirmed about this finding thorugh interview. Some students said that they were not allowed to bring cellphone to the school.

This is in line with the result of observation in which most students had good attention to the teacher especially when teacher delivered the material. Most of them did not talking with their friends nor playing cellphone. However, some students sitting in the back row sometimes talking with their friends and sometimes putting their head on the table. The second point is readiness. In this case, behaviour aspect can be seen through students' readiness both phisic and mental. The questionnaire filled by students shows that their confidence to raise their hand and give ideas was good. This finding is supported by the direct observation into some classes which found that student' contribution is extrimely low. Only when the teacher pointed them, they were willing to speak and give idea. The result then was supported by interview in which many students stated that they were not confident enough to give ideas. To tackle this, teacher needs to develop activity that can make students become more active.

The next aspect of behaviour is guided respons. The researcher did not included this in the questionnaire since it deals with body movement. Students were indicated having good behaviour at least if they do as what is instructed by the teacher. 
Based on the observation in three classes, all students followed the teacher's instruction well. For example, when teacher asked students' to perform, repeat after the teacher, do task in book and work in group. Even, in certain classes, students still did the task from the teacher when she had already left the class.

Still talking about students' movements which were not included in the questionnaire, they were divided into three namely accustome movement, complex movement and adjustment of the movement. Accustome movement is students' reaction in doing a very simple task. Based on the observation, several simple tasks were found such as memorize dialogue, make a list of names of things, made question about habitual action, etc. As long as the researcher observes them, most of them could do it since they worked in group in finishing that simple task. however, when they were asked to perform and share the result (complex movement with complex motion patterns), most of them seemed nerveous and not confident enough. It could be seen through their eyes and gesture.

In addition, based on the finding most of students were not able to adjust the movement based on the particular situation. For example, when students were asked to perform a dialogue about habitual action, they seemed monotonous. No gesture and expression. This case happened in B class. However, in I class students were able to make report of the interview. It was better, at least they could raise their ability not only the students could do interview but also made report. Unfortunately, many of them who came forward to share the result were still expressless and not willing to speak much.

Creativity is a very important aspect of learning. Creativity deals with the creation of new patterns of movement to adjust a particular situation. Based on the observation, students creativity is needed to be enhanced. This is the task of teacher to facilitate a creative learning. Memorization is good but it is not used to evaluate the performance. Then, in I class teacher needs to teach students about how to perform confidently and creatively. Actually the students in I class had already creative in creating question about habitual action and make report by using various pronoun, but then when it is presented they seemed nerveous. A different finding got from B class. The students in that class were tought to perfom confidently. For example, before performing students used opening then speak a loud. After they have finished, all students gave applouse. It can boost students' confidence and their creativiy to perform as well.

In short, every aspect of attitude actually was possitive. The result is in line with a study conducted by Shahrzad Eshghinejad, 2016, which found that both male and female students have positive emotional, behavioral, and cognitive attitudes toward English learning. Nevertheless, in every part of that aspect has their weaknesses. The dominant point needed to be enhanced in affective aspect is how to make students feel free and enjoy the learning, so their participation will increase. Further, if they have no worry of being wrong, or being nerveous to ask, it will be easier for them to achieve the intended goal of learning. Consequently their cognitive aspect will also enhance. In addition, it will also make them become more confident to perform or express the result of learning in front of class.

\subsection{Factors That Influencing Students' Attitude of Learning English}

There are some factors shaping students' attitude such as parents, teachers, learning climates and classroom task, refference group, personal experience and mass media. The instruments used by the 
researcher elicits some data wich can give information about which factors affecting students' attitude from the most dominant to the less dominant factors.

The diagram presented in the result section shows that the most dominant factor is mass media, then it was followed by refference group, teacher, personal experience, parents then learning climates and classroom

First, mass media. There are a lot of advantages of using this as a learning support. The researcher took one example of mass media that is internet. The questionnaire shows that most students strongly agreed that the use of internet and media technology could help them learning English. An interview were also conducted to deepen the result of questionnaire.

According to interview result, internet could help students to find difficult vocabularies, learning vocabularies through game, to translate word, sentences or texts and then find English material. Thus, mass media particularly internet and media technology such as handphone and computer could ease them in learning English.

Second, refference group. The role of friends is really important in bringing students into possitive or negative attitude. Based on the questionnaire result most students agreed that their friends could help them in learning English. That is the reason why in current curriculum students were expected to cooperate well with peer friends. In line with this, the interview shows that students had close friends which usually they could ask about difficult material.

Third, teacher. Teacher is the most important source of learning in the class. According to the result of questionnaire the tacher's teaching technique has already interesting and can boost students' mood to study. It can be seen that in the result section in which 35\% students agreed with the statement in compare to $34 \%$ of students with neutral respons. In line with this, when the researcer asked some students, the respons were also possitive. They said that the teacher's teaching technique was interesting especially the way teacher delivered the material. Furthermore, some students also stated that teacher is the factor that can motivate them to learn English. In addition, Salem Saleh Khalaf Ibnian (2017), states in his study that instructional methods, techniques and strategies used by teachers in the class highly affected the students' attitudes towards learning EFL.

In learning process of course it is the job of teacher to prepare media of learning. The role of media is also very important. Thus teacher needs to use an appropriate and interesting media to create fun teaching. Based on the questionnaire, it was found that most students were neutral in responding to that case. Then the researcher confirmed this in the interview. The result shows that the the media that was often used by teacher were video and power point slides. Those have already been interesting for students but here the researcher assumed that teacher needs to use more variouse media so that students will not feel bored.

Fourth, personal experience. Personal experience can be from inside and ouside the classroom. It is believed that personal experience can bring a drastic change in someone's attitude. According to the questionnaire most students opinion were neutral to the statement. Many of them also responded in the interview that they had no experience about learning English, nevertheless some of them said that they had good experience of learning English when they were tought by the teacher in junior high school. They felt happy of being tought by the teacher. In conclusion, only 
small number of students has good experience of learning English. Ideally, after studying, students will get experience that will be memorize in long time. Thus, this is antoher teacher's job to make students can get experience of learning.

Fifth, parents. Parents can bring possitive and negative attitdue towards learners who learn a foreign language. If the teacher motivates students to learn English then she/he is willing to help them finishing the task, it leads to possitive attitude for students. Table 4.2 in the result section shows that $64,3 \%$ parents could help students in learning, in which they could assist them did English homework. This is in line with the result of interview in which many students were helped by their parents or other part of families at home especially when they had tasks to do at home. If their parents could not teach them, they asked their sisters or brothers then. In conclusion, parents role is very important in shapping students' atttitude towards learning a foreign language, if parents have no knowledge of that language, it does not matter. Parents still can motivate them to study English by give children information about the essential of learning that language and pushing them to focus in learning.

Sixth, learning climates and classroom task. Learning climates deal with larning situation that can create fun learning. In this case, it is very important for the teacher to place students as the center of learning, so that they can get experience from learning and regard that the time of learning in the classroom is very valuable to just let it go. Centered learning means giving enough time for students to develop their skill. The questionnaire shows that accounting for $57,3 \%$, the factor of attitude is caused by learning climate and classroom task. This result regarded as fair. Moreover, based on the interview, students stated that teacher had already gave them sufficient time to discuss, then the classroom setting had already good and complete. Apart from that, teacher also gave appropriate task for students. As many of them stated that the task was easy to do especially when working in group.

However, there were some students shown their unsatisfaction towards the task given by teacher as they stated that the task was difficult especially in writing descriptive text and it was difficult to memorize certain vocabularies. In short, teacher still needs to imporve a good atmosphere that makes students become more active, comfort and enjoy the learning. In addition, the task will be more easier if the teacher prepares more authentic material.

\section{CONCLUSION}

According to the result of data analysis described in chapter IV, it reveals that students had good attitude towards learning English in terms of affective, cognitive and behavioural aspects. The presentage among those three aspect are graded from behaviour, then affective and cognitive. They are $68,8 \%, 68,1 \%$ and $64,7 \%$ respectively. Those percentages indicate good or possitive attitude. In addition, some indicators of each aspect is supported by the result of interview and observation.

Furthermore, this research also reveals that there are some factors affecting students attitude including mass media, refference group, teacher, personal experience, parents and the last is learning climates and classroom task. The research also reveals that the most dominant factor is mass media and the less dominant is learning climates and classroom tasks.

\section{REFERENCES}

Eshghinejad, Shahrzad. 2016. EFL students' attitudes toward learning English language: The case study of Kashan 
University students., page 1-13.

Retrieved on https://eric.ed.gov/?id=EJ1138277.

Ganapathy, Malini and Gooi Chiew Ying. 2016. "Attitude And Motivation Of Students Towards Learning English As Second Language In A Secondary School In Penang", Malaysian Journal of Languages and Linguistics, Edition No. 2, Volume 5, Page 39-56.

Hamzah, Syeh Hawib. 2012. “Aspek Pengembangan Peserta Didik (Kognitif, Afektif, Psikomotorik". Dinamika Ilmu. Vol 12. No. 1. Retrieved on https://journal.iainsamarinda.ac.id/index.php/dinami ka_ilmu/.

Ibnian, Salem Saleh Khalaf. 2017. "Attitudes of Public and Private Schools' Students towards Learning EFL", Internationanl Journal of Education, Edition No. 2, Volume 9.
Jafre, Mohamad Zainol Abidin. 2012. “EFL Students' Attitudes towards Learning English Language: The Case of Libyan Secondary School Students", Asian Social Science, Edition No. 2, Volume 8.

Lepy, Attitude and Social Cognition, Page 107-128. Retrieved on http://ncert.nic.in/ncerts/1/lepy106.p df.

Santoso, Agus. 2010. Scaffolding An EFL (English As Foreign Language) 'Effective Writing' Class In A Hybrid Learning Community. Retrieved on https://eprints.qut.edu.au/31811/.

Sulistyo, Urip. 2016. “English Language Teaching And EFL Teacher Competence In Indonesia", Proceedings of the Fourth International Seminar onEnglish Language and Teaching. 